\title{
Antibody-dependent and PHA-induced cellular cytotoxicity in rheumatoid arthritis
}

\author{
J. N. ROSENBERG AND H. L. F. CURREY \\ From the Bone and Joint Research Unit, London Hospital Medical College, London
}

SUMMARY One hundred and thirty nine observations of antibody-dependent cell mediated cytotoxicity (ADCC) were made on 77 patients with rheumatoid arthritis (RA) and 17 healthy controls. There were no differences in ADCC between these 2 groups or within the RA group with regard to disease activity, duration, seropositivity, or drug treatment. Sixty observations of phytohaemagglutinin induced cytotoxicity were made on 22 patients with RA and 10 healthy controls. Again there were no differences in cytotoxicity between the 2 groups.

The immunological activity apparent in rheumatoid arthritis (RA) has led to speculation that an altered state of immune reactivity may play a role in the development of this disease. It has also led to the clinical testing of drugs such as azathioprine thought to reduce immune responsiveness. However, numerous studies of immune reactivity in RA have produced conflicting results, with no consistent evidence of altered antibody production or specific cellular immunity. Rheumatoid patients have also generally not shown any consistent alteration in the numbers or ratios of circulating immunocyte subpopulations. In addition, effective treatment of RA by 'immunosuppressive' drugs is usually not associated with any obvious reduction in immune responsiveness, thus making it difficult to monitor this type of treatment (Currey, 1978).

Two in-vitro reactions provideconvenient measurements of the ability of separate subgroups of peripheral blood leucocytes to lyse target cells (Podleski, 1976). The one is antibody-dependent cell mediated cytotoxicity (ADCC), in which a subpopulation of lymphocytes (killer, or $\mathrm{K}$ cells) produces lysis of cells to which antibody is specifically bound (Perlmann and Perlmann, 1970); the other is phytohaemagglutinin (PHA)-induced cytotoxicity (Perlmann and Holm, 1969). Our interest in these 2 reactions arose from the observations of Campbell et al. (1976) that, in patients suffering from ulcerative colitis, azathioprine treatment produced a progressive

Accepted for publication 1 August, 1978

Correspondence to Professor H. L. F. Currey, Bone and Joint Research Unit, London Hospital Medical College, 25-29 Ashfield Street, London E1 2AD. reduction in both antibody-dependent and PHAinduced cytotoxicity in the peripheral blood. This therefore appeared to offer a method of monitoring 'immunosuppressive' therapy in RA. In addition, Wisloff $e$ t al. (1975) found patients with RA to have reduced PHA-induced cytotoxicity compared with nonrheumatoids.

For this reason we have used these 2 tests to seek differences between rheumatoid subjects and others, and, among patients with RA, differences between those receiving and those not receiving 'slow acting' drugs such as azathioprine.

\section{Patients}

Seventy-seven patients with classical or definite RA as defined by the American Rheumatism Association (Ropes, 1959) and 17 healthy persons were tested for ADCC. Treatment groups and clinical and laboratory details are shown in Table 1. The erythrocyte sedimentation rate (ESR) (Westergren) was used as a measure of disease activity. Drug dosage and duration of treatment were recorder for each patient. Among those taking azathioprine the mean cumulative dose was $75 \mathrm{~g}$ (range 3 to $272 \mathrm{~g}$ ), and the mean duration of therapy was $23 \cdot 5$ months (range 1 to 84 months.

Twenty-two patients with RA and 10 healthy persons were also investigated for PHA-induced cytotoxicity.

\section{Methods}

EFFECTOR CELLS

Lymphocytes were obtained from heparinised venous 
Table 1 Treatment groups: clinical and laboratory data

\begin{tabular}{|c|c|c|c|c|c|c|c|}
\hline Group & Healthy & $N S A I D$ & $A Z A$ & D-Pen & $G O L D$ & $A L C L$ & Corticosteroid \\
\hline $\begin{array}{l}\text { No. of subjects } \\
\text { Sex }(M: F) \\
\text { Mean age }(y r) \\
\text { Range } \\
\text { Disease duration (yr) } \\
\text { Range } \\
\text { ESR }(\mathrm{mm} / \mathrm{h}) \\
\text { Range } \\
\text { Latex + ve }(\geqslant 1 / 80)\end{array}$ & $\begin{array}{l}17 \\
8: 9\end{array}$ & $\begin{array}{l}16 \\
6: 10 \\
54 \cdot 4 \\
35-67 \\
11 \cdot 7 \\
4-34 \\
51 \cdot 8 \\
20-112 \\
13\end{array}$ & $\begin{array}{l}27 \\
11: 16 \\
56 \cdot 2 \\
38-70 \\
9 \cdot 1 \\
2-20 \\
54 \cdot 0 \\
3-121 \\
20\end{array}$ & $\begin{array}{l}16 \\
6: 10 \\
50 \cdot 0 \\
28-62 \\
8 \cdot 4 \\
2-15 \\
41 \cdot 6 \\
6-114 \\
15\end{array}$ & $\begin{array}{l}5 \\
1: 4 \\
47 \cdot 4 \\
34-68 \\
9 \cdot 0 \\
6-12 \\
24 \cdot 0 \\
10-42 \\
5\end{array}$ & $\begin{array}{l}8 \\
2: 6 \\
52 \cdot 6 \\
41-78 \\
12 \cdot 7 \\
4-23 \\
62 \cdot 7 \\
24-95 \\
8\end{array}$ & $\begin{array}{l}5 \\
2: 3 \\
54 \cdot 6 \\
44-73 \\
18 \cdot 6 \\
12-26 \\
45 \cdot 0 \\
43-120 \\
5\end{array}$ \\
\hline
\end{tabular}

NSAID $=$ Nonsteroidal anti-inflammatory drugs. $\quad \mathbf{A Z A}=$ Azathioprine. $\quad$ D-Pen $=$ D-penicillamine. $\quad \mathbf{A L C L}=\mathbf{A l c l o f e n a c}$.

blood as previously described (Vernon-Roberts et al., 1974). Medium 199, supplemented by $5 \%$ fetal calf serum of $\mathrm{pH} 7 \cdot 2$ was used throughout. The final cell suspension, containing $>85 \%$ lymphocytes with $>95 \%$ viability as assessed by trypan blue exclusion, was adjusted to $2 \cdot 5 \times 10^{7}$ cells $/ \mathrm{ml}$.

\section{TARGET CELLS}

Day-old chick red blood cells (CRBC) (Tissue Culture Services Ltd.) were incubated at $37^{\circ} \mathrm{C}$ for $2 \frac{1}{2}$ hours with radioactive sodium chromate, ${ }^{51} \mathrm{Cr}$ (Amersham). The labelled CRBC were washed and resuspended with unlabelled sheep red blood cells $\left(1 \times 10^{8} / \mathrm{ml}\right)$ to give a target cell concentration of $1 \times 10^{6} \mathrm{CRBC} / \mathrm{ml}$ and an effector to target cell ratio of $25: 1$.

\section{ANTIBODY}

An antiserum to CRBC was raised in a rabbit and stored in aliquots at $-20^{\circ} \mathrm{C}$. This was diluted to $1 \times 10^{-4}$ before use.

\section{ADCC ASSAY}

$50 \mu \mathrm{l}$ each of effector and target cell suspensions together with $50 \mu l$ antiserum were incubated at $37^{\circ} \mathrm{C}$ for 18 hours in the wells of Cooke Microtiter plates. All experiments were performed in triplicate, and appropriate controls were included in each run. A maximum release value was obtained by substituting $100 \mu 1$ of $3 \%$ Decon 90 detergent for the effector cell suspension and the antiserum. After incubation the tray was centrifuged at $200 \mathrm{~g}$ for 5 minutes. The ${ }^{51} \mathrm{Cr}$ content of $100 \mu l$ of supernatant from each well was then measured for 1 minute in a gamma guard 150 counter (Tracerlab Services Ltd.). Samples were randomised before counting.

\section{CALCULATION OF CYTOTOXICITY} INDEX (CI)

The median value for each triplicate determination was used.

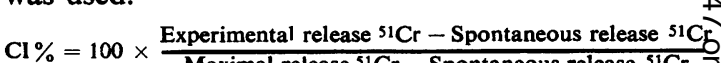
Maximal release ${ }^{51} \mathrm{Cr}-$ Spontaneous release ${ }^{51} \mathrm{Cr} J$

\section{PHA-INDUCED CYTOTOXICITY}

$50 \mu$ l PHA (Wellcome Reagents Ltd.) was substitute for antiserum in the system described above. The concentrations of PHA used were $3 \times 10^{-4}$ $3 \times 10^{-5}$, and $3 \times 10^{-6} \mathrm{mg} / \mathrm{ml}$.

\section{Results}

\section{ANTIBODY-DEPENDENT CELL MEDIATED} CYTOTOXICITY

One hundred and thirty-nine determinations of ADCC were made on the subjects described (Table 1 ) 3 The mean cytotoxicity index (CI) was similar fos patients and controls whether calculated overall of for individual treatment groups (Table 2). The meap CI for patients receiving 'slow acting' drug $\overline{\text { - }}$ (azathioprine, D-penicillamine, and gold) was $38 \cdot 2 \frac{2}{2}$ which was comparable to that in healthy people of patients in the group on nonsteroidal anti-inflamma@ tory drugs (NSAID). There were no statistically significant differences between any groups examined? Repeated observations on individual patients and healthy controls gave a consistency for $\mathrm{CI}$ over 6-month period within $10 \%$. These was no associan tion between CI and age, disease duration, ESR, or seropositivity as determined by a titred latex test (Table 3). Moreover the CI was unrelated to disease activity as assessed by the ESR in the group? examined (Table 4).

Table 2 Mean $C I$ in healthy and $R A$ treatment groups

\begin{tabular}{|c|c|c|c|c|c|c|c|}
\hline Group & Healthy & $N S A I D$ & $A Z A$ & D-Pen & Gold & $A L C L$ & Corticosteroid \\
\hline $\begin{array}{l}\text { Observations } \\
\text { Mean CI \% } \\
\text { SD }\end{array}$ & $\begin{array}{l}35 \\
35 \cdot 5 \\
14 \cdot 5\end{array}$ & $\begin{array}{l}17 \\
33 \cdot 7 \\
12 \cdot 2\end{array}$ & $\begin{array}{l}42 \\
38 \cdot 3 \\
11 \cdot 5\end{array}$ & $\begin{array}{l}26 \\
37 \cdot 1 \\
9 \cdot 4\end{array}$ & $\begin{array}{c}6 \\
39 \cdot 3 \\
13 \cdot 4\end{array}$ & $\begin{array}{c}8 \\
32 \cdot 3 \\
13 \cdot 3\end{array}$ & $\begin{array}{l}5 \\
40 \cdot 4 \\
7 \cdot 7\end{array}$ \\
\hline
\end{tabular}


Table 3 Relationship of latex titre and CI in rheumatoid patients

\begin{tabular}{lll}
\hline Latex titre & $\leqslant 1: 40$ & $\geqslant 1: 320$ \\
\hline No. of patients & 11 & 20 \\
Mean CI $\%$ & 37.4 & 37.6 \\
SD & 11.1 & 8.3 \\
\hline
\end{tabular}

Table 4 Relationship of ESR and CI within different treatment groups

\begin{tabular}{lll}
\hline Group & \multicolumn{2}{l}{ ESR mm/hour } \\
\cline { 2 - 3 } & $\leqslant 49$ & $\geqslant 50$ \\
\hline AZA & $37 \cdot 3$ & 39 \\
SD & 10.4 & $12 \cdot 6$ \\
D-Pen & $38 \cdot 7$ & $29 \cdot 8$ \\
SD & $10 \cdot 6$ & $7 \cdot 7$ \\
NSAID & $34 \cdot 5$ & 32.3 \\
SD & $10 \cdot 1$ & $15 \cdot 0$ \\
\hline
\end{tabular}

PHA-INDUCED CELLULAR

\section{CYTOTOXICITY}

Sixty determinations of PHA-induced cytotoxicity were made (Table 5). The results did not show any significant differences between the groups at the concentrations of PHA used. There was a comparable diminution in cytotoxicity in both groups for each reduction in PHA concentration.

Table 5 PHA-induced cytotoxicity in health and $R A$

\begin{tabular}{llllllr}
\hline & Health & \multicolumn{5}{c}{$R A$ (all drugs) } \\
\cline { 2 - 7 } PHA $(\mathrm{mg} / \mathrm{ml})$ & $\begin{array}{l}\text { Obser- } \\
\text { vations }\end{array}$ & $\begin{array}{l}\text { Mean } \\
\text { CI\% }\end{array}$ & $S D$ & $\begin{array}{l}\text { Obser- } \\
\text { vations }\end{array}$ & $\begin{array}{l}\text { Mean } \\
C I \%\end{array}$ & $S D$ \\
\hline $3 \times 10^{-4}$ & 9 & $36 \cdot 2$ & $13 \cdot 3$ & 12 & $36 \cdot 4$ & $9 \cdot 4$ \\
$3 \times 10^{-5}$ & 9 & 32.8 & $10 \cdot 3$ & 13 & $33 \cdot 8$ & $10 \cdot 2$ \\
$3 \times 10^{-6}$ & 9 & 21.4 & $13 \cdot 8$ & 8 & 16.6 & $6 \cdot 5$ \\
\hline
\end{tabular}

\section{Discussion}

This study does not indicate any differences in peripheral blood $\mathrm{K}$ cell activity between $\mathrm{RA}$ and health, which accords with the findings of Wisloff et al. (1975), Fröland et al. (1975), and Feldmann et al. (1976). These authors used a similar CRBC system. Panayi and Corrigall (1977) obtained comparable results using a Chang cell system. There are, however, reports of both increased (Sany et al., 1976) and decreased ADCC in RA (Isturiz et al., 1976; McGill and Twinn, 1977). It has been suggested that a reduction in ADCC might be due to a blocking effect of immune complexes in these patients. Discrepant results could also reflect differences in technique. These include the method of lymphocyte separation (Mookerjee, 1976), varying effector target cell ratios, and incubation periods.
McGill and Twinn (1977) correlated ADCC with seropositivity and disease activity. However, 14 of their 39 seropositive patients had a CI of $10 \%$ or less, of whom 7 had no demonstrable cytotoxicity. Only 1 of our patients had a CI of less than $10 \%$, and we were unable to find any correlation between cytotoxicity and disease activity or seropositivity.

Drug treatment, in particular azathioprine, did not appear to influence ADCC in our RA patients. The fall in ADCC following azathioprine therapy reported by Campbell et al. (1976) occurred in patients receiving the drug for ulcerative colitis, not RA. Furthermore, these authors employed a Chang cell system and calculated $\mathrm{CI}$ in a manner which makes comparisons with our own and other studies difficult.

Our results do not confirm the reduction in PHAinduced cytotoxicity in RA reported by Wisloff et al. (1975). Differences in the method of separating lymphocytes might possibly explain this discrepancy, for mitogenic responses of lymphocytes in RA vary with the subpopulation examined (Silverman et al., 1976; Rawson and Huang, 1976).

In conclusion, our studies of cellular cytotoxicity have not revealed any alterations attributable to RA or drugs, including azathioprine.

We are grateful to Mr Stephen Evans for statistical advice and comment, and to Dr Paul Zilko for help with developing the method. J. N. Rosenberg was in receipt of an Arthritis and Rheumatism Council travelling fellowship.

\section{References}

Campbell, A. C., Skinner, J. M., Maclennon, I. C. M., Hersey, P., Waller, C. A., Wood, J., Jewell, D. P., and Truelove, S. C. (1976). Immunosuppression in the treatment of inflammatory bowel disease: II. The effects of azathioprine on lymphoid cell populations in a double blind trial in ulcerative colitis. Clinical and Experimental Immunology, 24, 249-258.

Currey, H. L. F. (1978). Therapeutic alteration of immune responses in rheumatoid arthritis: Is it relevant? Proceedings of the Royal Society of Medicine, 71, 275-277.

Feldmann, J.-L., Becker, M. I., Moutsopoulos, H., Fye, K., Blackman, M., Epstein, W. V., and Talal, N. (1976). Antibody-dependent cell mediated cytotoxicity in selected autoimmune diseases. Journal of Clinical Investigation, 58, 173-179.

Fröland, S. S., Natvig, J. B., and Wisloff, F. (1975). Lymphocyte subpopulations in rheumatoid arthritis. Rheumatology, 6, 231-241.

Isturiz, M. A., de Bracco, M. M. de E., Pizzi, A. M., and Manni, J. A. (1976). Antibody-dependent cell mediated cytotoxicity in rheumatoid arthritis. Arthritis and Rheumatism, 19, 725-730.

McGill, P. E., and Twinn, I. (1977). Antibody-mediated cytotoxicity in rheumatoid arthritis. Annals of the Rheumatic Diseases, 36, 268-270.

Mookerjee, B. K. (1976). Influence of separation techniques on the distribution and function of lymphocyte subpopulations a comparison of three techniques. Transplantation, 22, 101-107. 
Panayi, G. S., and Corrigall, V. (1977). Functional assay of cytotoxic lymphocytes involved in antibody-mediated cytotoxicity in normal and rheumatoid subjects. Annals of the Rheumatic Diseases, 36, 257-260.

Perlmann, P., and Holm, G. (1969). Cytoxic effects of lymphocytes in vitro. In Advances in Immunology, 11, 117-193. Edited by F. J. Dixon and H. G. Kunkel. Academic Press: New York and London.

Perlmann, P., and Perlmann, H. (1970). Contactual lysis of antibody-coated chicken erythrocytes by purified lymphocytes. Cellular Immunology, 1, 300-315.

Podleski, W. K. (1976). Cytodestructive mechanisms provoked by lymphocytes. American Journal of Medicine, 61, 1-8.

Rawson, A. J., and Huang, I. C. (1976). Lymphocyte populations in rheumatoid arthritis. Arthritis and Rheumatism, 19, 720-724.
Ropes, M. W. (1959). Diagnostic criteria for rheumatoic arthritis: 1958 revision. Annals of the Rheumatic Diseases; 18, 49-53.

Sany, J., Clot, J., Frietas, M., Charmasson, E., and Serre, $\mathrm{H}_{\stackrel{?}{?}}$ (1976). Antibody-dependent cell cytotoxicity (ADCC) oष rheumatoid arthritis blood lymphocytes. Revue di্ত
Rheumatisma, 43, 333-338.

Silverman, H. A., Johnson, J. S., Vaughan, J. H., an McGlamory, J. C. (1976). Altered lymphocyte reactivite in rheumatoid arthritis. Arthritis and Rheumatism, 19: 509-515.

Vernon-Roberts, B., Currey, H. L. F., and Perrin, J. (1974)? $\mathrm{T}$ and $\mathrm{B}$ cells in the blood and synovial fluid of rheumatoid patients. Annals of the Rheumatic Diseases, 33, 430-434. Wisloff, F., Fröland, S. S., and Natvig, J. B. (1975). Deficien? lymphoid cell mediated, PHA-induced cytotoxicity i rheumatoid arthritis patients. Scandinavian Journal of Immunology, 4, 303-307. 